\title{
The Relation of Size to the Relative Rates of Degradation of Intestinal Brush Border Proteins
}

\author{
Davim H. Alpers \\ From the Department of Medicine, Washington University School of Medicine, \\ St. Louis, Missouri 63110
}

A B S T R A C T Proteins associated with intestinal brush borders and their various fractions were solubilized with sodium dodecyl sulfate and $\beta$-mercaptoethanol, and separated by electrophoresis on acrylamide gels containing sodium dodecyl sulfate. Brush borders contain at least 15 proteins or subunits, ranging in molecular weight from 19,000 to 270,000 . The largest proteins (170-270,000 $\mathrm{mol} \mathrm{wt}$ ), including the disaccharidases, are removed from the brush borders by papain. Proteins belonging to the remaining membrane, including alkaline phosphatase, have an intermediate size (53$140,000 \mathrm{~mol} \mathrm{wt}$ ). The proteins corresponding to the filamentous "core" of the microvilli are the smallest $(19-45,000)$.

The relative rates of degradation of these proteins were studied by following the rate of decline of ${ }^{14} \mathrm{C}$ labeled leucine activity in specific proteins, and by the double isotope technique of Schimke in which leucine${ }^{14} \mathrm{C}$ was given to intact rats intraluminally $10 \mathrm{hr}$ before an intraluminal dose of leucine- ${ }^{3} \mathrm{H}$. Heterogeneity of ${ }^{3} \mathrm{H} /{ }^{14} \mathrm{C}$ ratios and thus of rates of turnover of brush border proteins was noted. In general, the largest proteins (including the disaccharidases), were turning over the fastest. Other membrane proteins (i.e. alkaline phosphatase) had an intermediate rate of degradation, and "core" proteins turned over slowly. Thus, there was a general correlation between relative degradation rate and size.

\section{INTRODUCTION}

A number of studies have shown heterogeneity of intracellular protein turnover rates $(1,2)$, and, moreover, that the proteins of various membranes are turning

This work was presented in part at a meeting of the American Gastroenterological Association in Bal Harbour, Fla., 15 May 1971.

Received for publication 10 March 1972 and in revised form 22 June 1972. over at a rapid rate (3). Furthermore, studies on the turnover of specific membrane proteins $(4,5)$ or groups of proteins (6) demonstrated a heterogeneity in the rate of turnover among membrane proteins. The brush border of the intestine is a complex membrane system consisting of a bimolecular membrane which includes specific hydrolases (7) and to which is attached a filamentous "core" providing structure to the microvilli. These fractions have been separated and characterized by Eichholz and Crane (8).

In the present study we have examined the relative rates of turnover of the protein components of intestinal brush borders as separated by electrophoresis on polyacrylamide gels in the presence of sodium dodecyl sulfate (SDS). ${ }^{1}$ This system is capable of separating proteins according to their apparent molecular weight. Using such a system, we have examined the correlation between anatomic location on the brush border, molecular size, and rate of degradation.

\section{METHODS}

Brish border isolation and fractionation. Brush borders were prepared by the method of Forstner, Sabesin, and Isselbacher (9). Samples to be fractionated were treated

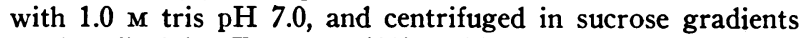
as described by Forstner (10). This allows preparation of quite pure membrane fractions, but the filamentous or "core" fraction remains contaminated with membranous elements. For papain treatment, brush borders were suspended in potassium phosphate buffer $0.1 \mathrm{M} \mathrm{pH} 7.2$ at a concentration of 3-4 mg protein per $\mathrm{ml}$, and sonicated in a Bronwill probe sonicator for $30 \mathrm{sec}$ at the lowest setting. Papain (Sigma Chemical Corp., St. Louis, Mo.) $0.1 \mathrm{mg} / \mathrm{ml}$, and cysteine $1.0 \mathrm{mg} / \mathrm{ml}$ were added to this suspension. Incubation was performed at $37^{\circ}$ for $30 \mathrm{~min}$ and the brush borders were centrifuged at $105,000 \mathrm{~g}$ for $60 \mathrm{~min}$. The supernatant and the sedimented brush borders were recovered and used for electrophoretic studies.

Isotope administration. ${ }^{14} \mathrm{C}$-labeled L-leucine (U. L. 255 $\mu \mathrm{Ci} / \mu$ mole) and ${ }^{3} \mathrm{H}$-labeled L-leucine $(41 \mathrm{mCi} / \mu$ mole $)$ were

${ }^{1}$ Abbreviations used in this paper: ME, mercaptoethanol; PAS, periodic acid-Schiff; SDS, sodium dodecyl sulfate. 
obtained from New England Nuclear Corp., Boston, Mass. Wistar rats, 160-200 g (National Laboratory Animal Co., Creve Coeur, Mo.) were anesthetized with ether, and their abdomens opened. A 4-0 silk ligature was looped around the intestine to mark the site of injection just distal to the ligament of Treitz. At this point $25 \mu \mathrm{Ci}$ of leucine $-{ }^{14} \mathrm{C}$, dissolved in $2 \mathrm{ml}$ of normal saline, was injected through a No. 26 needle into the intestinal lumen. The intestine was not irrigated before injection. The hole was sealed with Eastman adhesive 910, the distal extent of the intraluminal fluid marked by another loose ligature, and the abdomen was closed with metal clips. This injection was made at 11 p.m. to rats fasted since 4 p.m., but allowed access to water. Animals remained fasted throughout the rest of the experiment. At 9 a.m. the following morning the procedure was repeated, using $50 \mu \mathrm{Ci}$ of leucine- ${ }^{3} \mathrm{H}$. Animals were sacrificed $8 \mathrm{hr}$ after the second injection (i.e. at 5 p.m.). In some experiments, the order of administering isotopes was reversed.

After sacrifice, the intestine was removed between the two ligatures and washed with $50 \mathrm{ml}$ of normal saline. The mucosa was removed by scraping with glass slides, and brush borders were prepared. For a few experiments, the mucosa was not scraped, but the entire intestinal thickness cut into $1 \times 1 \mathrm{~cm}$ squares and placed on a cryostat chuck prepared with $\mathrm{O}$. C. T. in such a way that the intestinal villi were perpendicular to the cutting surface. Sections $10 \mu$ thick were then cut, using three consecutive sections for biochemical analysis, and the fourth for histological confirmation of position along the villus, as described previously (11). Three $10 \mu$ samples were precipitated with $10 \%$ trichloracetic acid, washed three times with the same acid. air dried, and solubilized with $0.5 \times \mathrm{NaOH}$. Portions of this solution were then taken for analysis of radioactivity (see below) and for protein, by the method of Lowry, Rosebrough, Farr, and Randall (12).

Acrylamide gel electrophoresis. Sodium dodecyl sulfate (SDS) and 2-mercaptoethanol (ME) were added to samples of brush borders in $0.1 \mathrm{M}$ sodium phosphate buffer pH 7.2 to a final concentration of $3 \%$ and $1 \%$, respectively. Samples were then heated to $65^{\circ} \mathrm{C}$ for $1 \mathrm{hr}$. Glycerol was added to make a $20 \%$ solution, and bromphenol blue was used as a tracking dye. Gel electrophoresis was performed by a modification of the method of Dunker and Rueckert (13), using gels $6 \times 120 \mathrm{~mm}$. The gel solution contained $5 \%$ acrylamide, $0.167 \%$ bis acrylamide, $0.1 \%$ SDS, 0.1 м sodium phosphate, $\mathrm{pH} 7.2$, and $0.1 \% \quad \mathrm{~N}, \mathrm{~N}, \mathrm{~N}, \mathrm{~N}^{\prime}$-tetramethylethylenediamine. Gel formation was initiated by ammonium persulfate. The gel solution was carefully overlaid with $0.1 \%$ SDS, and the gels were allowed to stand at room temperature for at least $12 \mathrm{hr}$ before use (14). Large gels, $19 \times 75 \mathrm{~mm}$, were used for some radioactive samples, since such gels could resolved up to $5 \mathrm{mg}$ of protein. Samples of brush border containing from 50-350 $\mu \mathrm{g}$ protein were applied to each small gel and up to $5 \mathrm{mg}$ to each large gel. No change in patterns was detected over this range, but on amounts greater than $40 \mu \mathrm{g}$ the protein patterns became somewhat distorted and showed indistinct separation. For most studies, $300 \mu \mathrm{g}$ of protein was used, containing 2000 $5000{ }^{3} \mathrm{H}$ counts and $1000-1500{ }^{14} \mathrm{C}$ counts $/ \mathrm{min}$. The samples were overlaid with $0.1 \mathrm{M}$ sodium phosphate buffer, $\mathrm{pH} 7.2$ containing $0.1 \%$ SDS and $0.05 \% \mathrm{ME}(0.1 \mathrm{M})$. The cathode solution contained only phosphate buffer. Electrophoresis was carried out in gels $6 \mathrm{~mm} \times 120 \mathrm{~mm}$ at 8 ma per gel for $9 \mathrm{hr}$, or in $19 \times 75 \mathrm{~mm}$ gels at $80 \mathrm{ma}$ per gel.
After electrophoresis the gels were removed and stained according to Fairbanks, Steck, and Wallach (14). Gels were placed overnight in a solution containing $25 \%$ isopropyl alcohol, $10 \%$ acetic acid, and $0.025 \%$ Coomassie Blue, the next day transferred to a solution containing $10 \%$ isopropyl alcohol, $10 \%$ acetic acid, and $0.0025 \%$ Coomassie Blue for 6-9 hr, and finally destained overnight in $10 \%$ acetic acid.

Apparent molecular weight was estimated by applying 20 $\mu \mathrm{g}$ of marker proteins to the analytical gels. The proteins used included $\beta$-galactosidase $(130,000)$, phosphorylase (94,$000)$, fibrinogen and chain $(73,000), \beta$-chain $(60,000)$, and $\gamma$-chain $(53,000)$, catalase $(60,000)$, aldolase $(40,000)$, pep$\sin (35,000), \gamma \mathrm{G}$ light chain $(22,000)$, and globin $(15,500)$. When migration was plotted against the $\log$ molecular weight, a linear relationship was found. For molecular weight determinations, marker proteins were electrophoresed simultaneously with brush border proteins. Since many brush border proteins are glycoproteins, the molecular weight determined is an estimate only (13).

Densitometry was performed on the stained gels by scanning the gels with a Gilford Model 2410 linear transport at $555 \mathrm{~m} \mu$. The area under each peak was measured by triangulation using a planimeter (Gelman Instrument Company, Ann Arbor, Mich.), and the amount of protein calculated from a standard curve using human albumin. Human albumin produces three peaks in SDS acrylamide electrophoresis. The area for these peaks was combined and a linear and very reproducible curve was found up to at least $60 \mu \mathrm{g}$ of albumin. This is similar to a method used with Fast Green as the stain (15). Using up to 200 $\mu \mathrm{g}$ of protein on the gel, we did not exceed $60 \mu \mathrm{g}$ for any single protein peak. Such quantitation was used only in experiments where the specific activity of a specific protein was compared with the same protein at other times, not with other proteins. Thus, the possible differential staining by Coomassie Blue of various proteins would not be an important factor.

Gels were stained histochemically for alkaline phosphatase and maltase, neither of which lost all their activity in the presence of SDS. Alkaline phosphatase activity was detected by placing gels in a freshly prepared solution containing (per $100 \mathrm{ml}$ ) $50 \mathrm{mg}$ sodium $\beta$-napthyl phosphate, $50 \mathrm{mg}$ Diazo Blue $\mathrm{B}, 1 \mathrm{ml}$ of $10 \mathrm{mM} \mathrm{MgCl}$, and $15 \mathrm{ml}$ of $50 \mathrm{~mm}$ sodium barbital, $\mathrm{pH} 9.4$ (16), and incubating for 4-12 hr. Maltase activity was detected by placing the gels in a solution containing (per $\mathrm{ml}$ ) gelatin $5 \mathrm{mg}$ phenazine methosulfate $0.05 \mathrm{mg}$, tetranitro blue tetrazolium $0.33 \mathrm{mg}$. glucose oxidase (Mann Research Labs, Inc., New York) 0.2 $\mathrm{mg} / \mathrm{ml}$, and maltose $2.5 \mathrm{mg}$ ( 17 ).

Patterns of brush border proteins were identical under all conditions, whether samples were heated or not, allowed to stand overnight, or greatly concentrated. There was no evidence of degradation during solubilization or of formation of aggregates regardless of the time in SDS prior to electrophoresis. During electrophoresis, however, some material precipitated on the top of the gel and did not enter. By densitometry and recovery of radioactivity $75-80 \%$ of the applied protein was recovered in the gel. Since the recovery is the same for protein and radioactivity, we assume that what is recovered on the gel is a representative sample of the original brush border.

Radioactiz' counting of acrylamide gels. Gels were counted in one of two ways-by extrusion or slicing. Gels assayed by extrusion were placed in a Savant model AGD- 


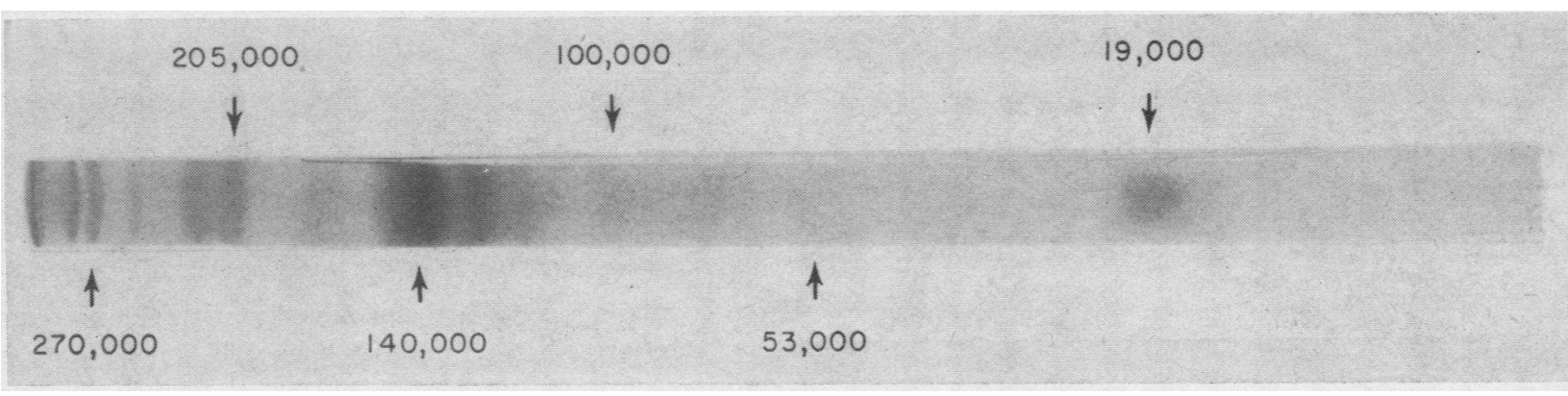

FIGURE 1 Molecular weight determination of brush border proteins. $200 \mu \mathrm{g}$ of brush border protein were electrophoresed on SDS acrylamide gels as described in Methods. Protein standards were run simultaneously in parallel as described in Methods, and the molecular weight determined by the migration distance along the gel. Where the bands were diffuse, the distance used for calculation was the midpoint of the stained protein band. The direction of electrophoresis is from cathode on the left to anode on the right.

$30 \mathrm{~A}$ extruder and fractions equivalent to $4 \mathrm{~mm}$ were collected directly in counting vials, using water as the extruding fluid. The Savant extruder was modified by cutting the eluting tubing to a length of $12 \mathrm{~cm}$, thus making peaks sharper. Moreover, by extruding a $6 \mathrm{~mm}$ gel in the tubing designed for $5 \mathrm{~mm}$ gels, undue compression of gels before extrusion was eliminated, and the variation in counts evenly distributed throughout the gel was less than $10 \%$ in each fraction recovered. For each extruded gel, a duplicate gel was stained, and the pattern of protein staining could then be transferred to the radioactive pattern. To each counting vial containing about $1.0 \mathrm{ml}$ of water and extruded gel was added $7 \mathrm{ml}$ of Bray's solution (18) with an efficiency for ${ }^{14} \mathrm{C}$ and ${ }^{3} \mathrm{H}$ of $67 \%$ and $25 \%$, respectively, as measured by external standard in a Packard Model 3320 Spectrometer (Packard Instrument Co., Inc., Downers Grove, Ill.). When double-labeled experiments were performed, the efficiency for ${ }^{14} \mathrm{C}$ and ${ }^{3} \mathrm{H}$ was $43 \%$ and $21 \%$, respectively, with no ${ }^{3} \mathrm{H}$ counts in the ${ }^{14} \mathrm{C}$ window and $8 \%$ of ${ }^{14} \mathrm{C}$ counts in the ${ }^{3} \mathrm{H}$ window.

Large $(19 \times 75 \mathrm{~mm})$ gels were first stained with Coomassie Blue and the appropriate slices cut by hand using a Stadie-Riggs microtome blade and a plexiglass support which directed the blade at a right angle to the gels. Gel slices were then dried overnight in a counting vial, covered with $0.2 \mathrm{ml}$ of $30 \% \mathrm{H}_{2} \mathrm{O}_{2}$, and heated in the stoppered vial at $37^{\circ}$ until the gel had dissolved. $2 \mathrm{ml}$ of $\mathrm{NCS}(\mathrm{Nu}-$ clear Chicago, Des Plaines, Ill.) solubilized was then added, along with $10 \mathrm{ml}$ of Toluene containing $0.4 \%$ 2,5-diphenyloxazole and $0.08 \%$-bis-(0-methylstyryl)-benzene. For single-labeled experiments, efficiency was $79 \%$ and $44 \%$, respectively, for ${ }^{14} \mathrm{C}$ and ${ }^{3} \mathrm{H}$; for double-labeled experiments the efficiency was $52 \%$ and $35 \%$. All samples were counted for at least 2000 counts above background, equivalent to a probable counting error of $1.5 \%$.

\section{RESULTS}

Electrophoretic fractionation of brush border proteins by molecular weight. When whole brush borders were separated on SDS acrylamide gel electrophoresis, a pattern of protein was found as depicted in Fig. 1. Proteins were found with molecular weights varying from 19,000 to 270,000 . Although poorly seen in the photograph, there are two or three bands between 270 ,-
000 and 205,000, three more between 53,000 and 19,000, and one or two bands which run faster than 19,000 .

Brush borders were then separated into membrane and "core" fractions on sucrose gradients and again analyzed on SDS gels. Fig. 2 demonstrates diagrammatically the protein pattern obtained from the membrane fraction as compared with the entire brush border. It is apparent that the membrane fraction included many if not all of the large proteins in the brush border, but contained almost no detectable protein with a molecular weight less than 60,000 . When the gels were stained with periodic acid-Schiff (PAS), none of the "core" proteins could be identified as glycoproteins, but most of the papain-solubilized proteins and the other membrane proteins took up PAS stain. When the membrane fraction was treated with papain, most, but not all, of the proteins larger than $140,000 \mathrm{~mol} \mathrm{wt}$ were not found in the resulting particulate fraction, but could be recovered from the $105,000 \mathrm{~g}$ supernatant. Papain treatment released at least five of the brush border proteins with molecular weights greater than

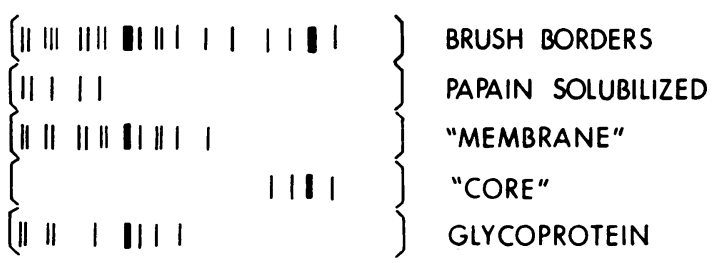

FIGURE 2 Schematic representation of brush border proteins. The brush borders were prepared, fractionated, and treated with papain as described in Methods. The upper four gels were stained with Coomassie Blue, the lower one with PAS stain $(19,14)$. Direction of electrophoresis was from cathode on the left to anode on the right. The proteins are schematically represented in the figure with the width of the band roughly corresponding to the intensity of the stain. The largest proteins are depicted to the left of the diagram. 


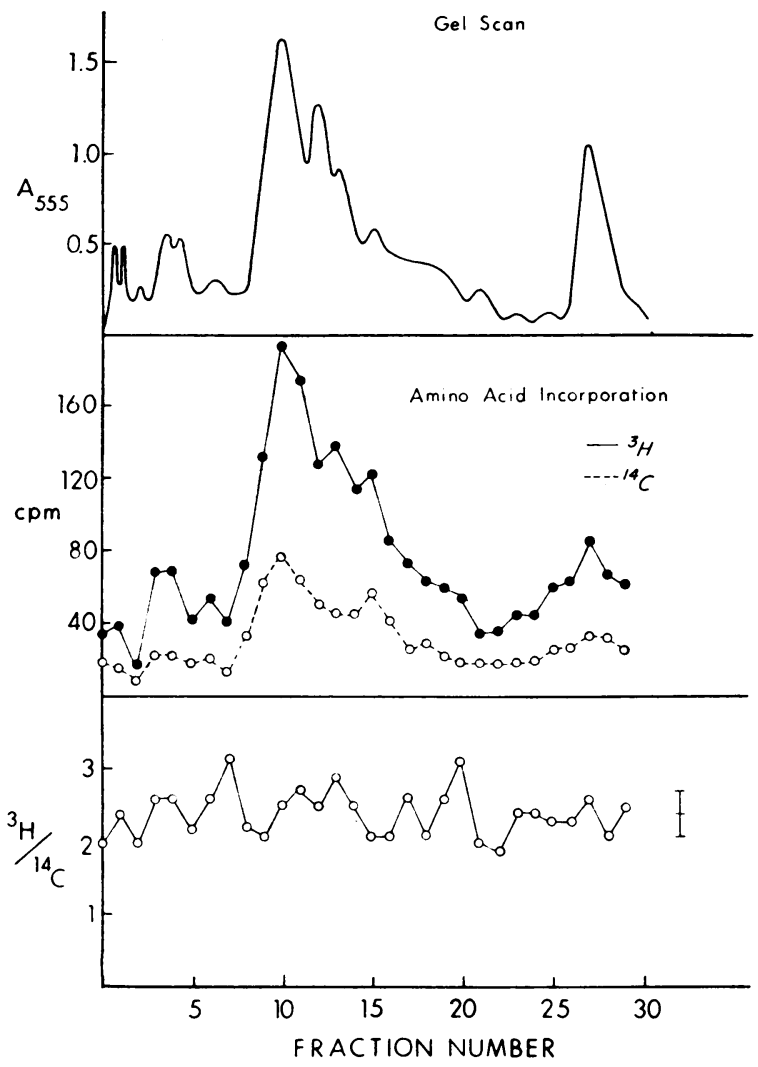

FIGURE 3 Electrophoretic pattern of radioactivity and optical density of brush border proteins. $25 \mu \mathrm{Ci}$ of leucine ${ }^{14} \mathrm{C}$ and $50 \mu \mathrm{Ci}$ of leucine- ${ }^{3} \mathrm{H}$ were placed intraluminally in two animals as described in Methods, and the animals were killed $8 \mathrm{hr}$ later. Electrophoretic separation of $300 \mu \mathrm{g}$ of protein was performed in three $6 \times 120 \mathrm{~mm}$ gels, with the origin to the left of the diagram. The upper box displays the optical density scan of a Coomassie Blue-stained gel, and the lower two boxes reveal the counts and ${ }^{3} \mathrm{H} /{ }^{14} \mathrm{C}$ ratios of the gel fractions from two gels extruded as described in Methods. The fractions from two gels were combined to increase the number of counts.

140,000 , including sucrase, maltase, and lactase. It is possible that not all large proteins are released, or that some proteins aggregate during papain treatment and subsequent concentration before electrophoresis. The papain-released proteins correspond to some of the proteins whose function seems extracellular (20) but whose exact location on the membrane is unresolved at present. The "core" fraction is not a pure fraction. being contaminated with small amounts of membrane elements. However, no protein bands with a molecular weight less than 53,000 were found in the pure membrane fraction. Thus, we can deduce (cf. Fig. 2) that most proteins of the "core" fraction are small, and less than 53,000 mol wt. The protein band at 53,000 mol wt was sometimes found in the membrane fraction, so that it is unclear to which brush border fraction this protein belongs.

Certain specific proteins could be identified by histochemical staining. The heaviest stained protein band $(140,00 \mathrm{~mol} \mathrm{wt})$ displayed alkaline phosphatase activity histochemically, and the molecular weight of 140,000 agrees well with other estimates of intestinal alkaline phosphatase. There are undoubtedly multiple proteins for each protein band, so that one could not be certain how much of the protein of $i 40,000 \mathrm{~mol}$ wt is alkaline phosphatase. Maltase activity was identified in the protein with a molecular weight of 205,000 although less activity survived SDS electrophoresis than was the case or alkaline phosphatase. Sucrase and lactase activity did not survive SDS treatment, but have molecular weights similar to maltase $(21,22)$, again demonstrating the likelihood of multiple proteins in each band separated by electrophoresis.

The relative frequency of these proteins in the brush border was estimated by densitometry. This comparison assumes, of course, that the degree of staining by Coomassie Blue was roughly comparable for all proteins, which is not the case, since stain uptake may differ by two- or threefold. However, stain uptake is unlikely to differ by so much as the recorded differences between proteins, so it was felt that certain comparisons could be fairly made. Table I demonstrates that the

TABLE I

Relationship of Amount of Protein to Molecular IVeight in Intestinal Brush Borders

\begin{tabular}{ccc}
\hline $\begin{array}{c}\text { Electro- } \\
\text { phoretic } \\
\text { fraction }\end{array}$ & $\begin{array}{c}\text { Average } \\
\text { molecular } \\
\text { weight } \\
\left(\times 10^{-3}\right)\end{array}$ & $\begin{array}{c}\text { Amount of } \\
\text { protein }\end{array}$ \\
\hline & & $\begin{array}{c}\text { \% of tolal } \\
\text { protein }\end{array}$ \\
1 & 19 & 20.5 \\
2 & 32 & 0.5 \\
3 & 41 & 0.6 \\
4 & 53 & 2.6 \\
5 & 70 & 3.6 \\
6 & 100 & 4.7 \\
7 & 115 & 6 \\
8 & 132 & 11.1 \\
9 & 140 & 28.2 \\
10 & 170 & 4.4 \\
11 & 212 & 12.4 \\
12 & 245 & 1.3 \\
13 & 270 & 4.1 \\
\hline
\end{tabular}

Brush border proteins were electrophoresed and stained, and their relative frequencies were determined by densitometric scanning of the gel, as described in Methods. The area under each curve as a per cent of the total area is recorded as the per cent of total protein. 
major core protein (fraction 1) and alkaline phosphatase (fraction 9) accounted for almost one-half of all the brush border proteins. Moreover, if the "core" fractions 1-4 are not included, alkaline phosphatase accounted for one-third of the remaining protein.

Turnover of membrane fractions. To measure turnover, we have used the double isotope technique first described by Arias, Doyle, and Schimke (23) for studying the Triton X-100 solubilized protein constituents of liver membranes, and later by Dehlinger and Schimke (6) for SDS acrylamide fractionation. In most of the following experiments pulse labeling was achieved by injecting leucine- ${ }^{14} \mathrm{C}$ first, followed by leucine- ${ }^{3} \mathrm{H}$. For any protein, the level of the second isotope indicates incorporation $8 \mathrm{hr}$ after the second pulse label, whereas the initial isotope indicates incorporation $18 \mathrm{hr}$ after the first pulse label. Protein turning over rapidly will incorporate leucine- ${ }^{3} \mathrm{H}$ rapidly and have high ${ }^{3} \mathrm{H} /{ }^{14} \mathrm{C}$ ratios. If there is no differential turnover between proteins, they will have the same ${ }^{8} \mathrm{H} /{ }^{44} \mathrm{C}$ ratio.

A control experiment was first performed in order to determine how much variation was inherent in the

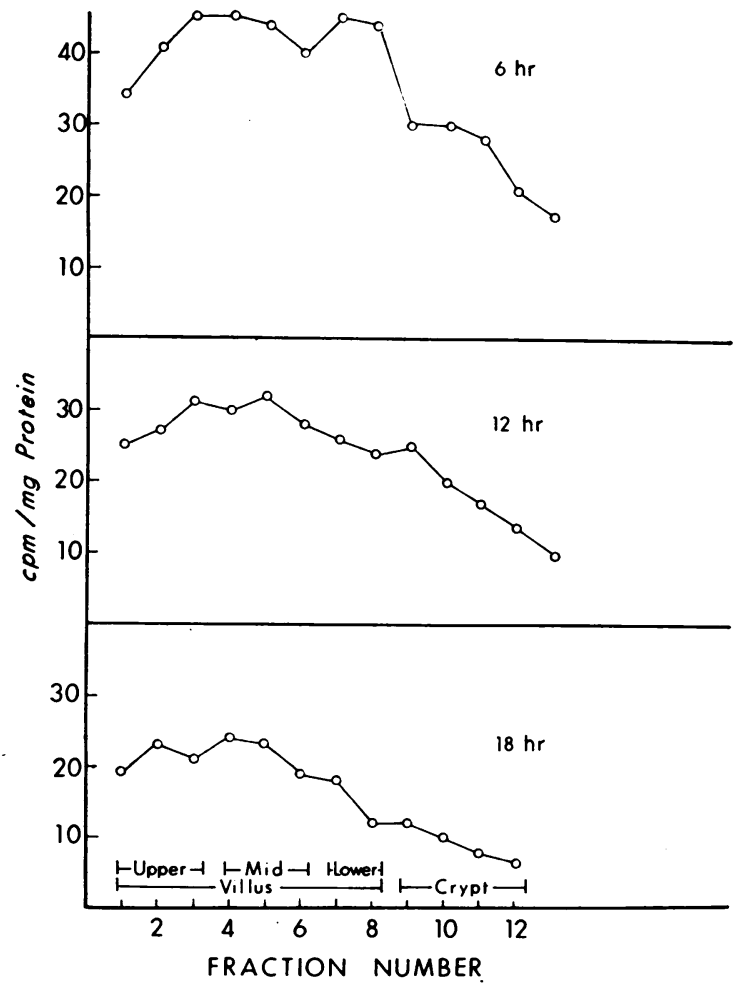

FIgURE 4 Incorporation of leucine into protein along the villus as a function of time. To each of six rats $50 \mu \mathrm{g}$ of leucine- ${ }^{3} \mathrm{H}$ was placed in the jejunum as described in Methods. The tissue was sliced on a cryostat and analyzed as described in Methods. The morphological position along the villus to which the fractions correspond is listed at the bottom of the slide.

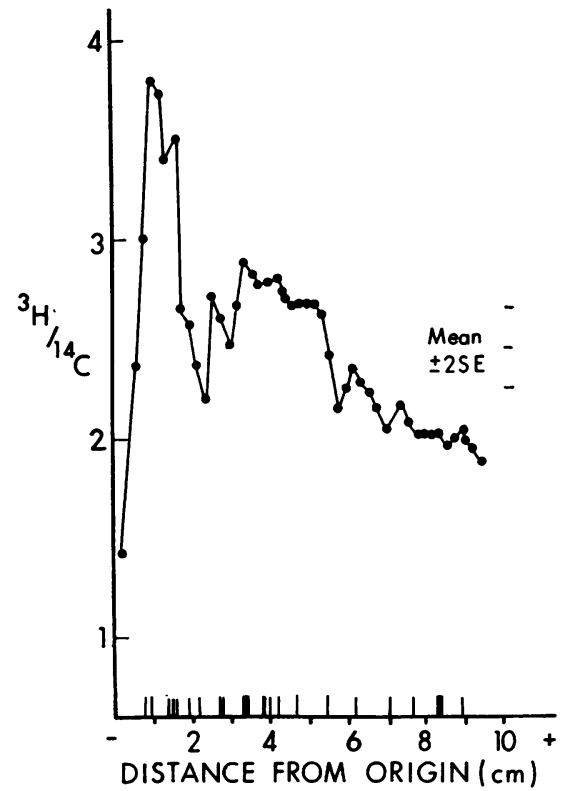

FIgURE 5 Relative turnover rates of intestinal brush border proteins. $25 \mu \mathrm{Ci}$ of leucine ${ }^{-14} \mathrm{C}$ was given intraluminally to two rats, followed at $10 \mathrm{hr}$ by $50 \mu \mathrm{Ci}$ of leucine- ${ }^{3} \mathrm{H}$. Brush borders were isolated $8 \mathrm{hr}$ later. Three SDS gels were electrophoresed with $300 \mu \mathrm{g}$ of brush border protein as described in Methods. One gel was stained with Coomassie Blue, the other two were extruded and counted as outlined in Methods. The fractions from two gels were combined. Electrophoresis was from left to right. Counts per minute above background ranged from 32 to 124 for ${ }^{3} \mathrm{H}$ and from 16 to 74 for ${ }^{14} \mathrm{C}$.

technique. In this experiment, both isotopes were delivered simultaneously and the animal sacrificed $10 \mathrm{hr}$ later. The results (Fig. 3) are similar to those achieved by Dehlinger and Schimke (6). The greatest amount of incorporation occurred in fractions corresponding to alkaline phosphatase (fraction 10) and other membrane proteins (fractions $11-18$ ). The mean ${ }^{8} \mathrm{H} /{ }^{44} \mathrm{C}$ ratio was $2.41 \pm 0.21$ (SE). This mean varied some from experiment to experiment, but the degree of variation was similar. It is of note that, although the major "core" protein (fractions 26-29) accounts for over $20 \%$ of the brush border protein (Table I), it was not very actively synthesized.

The length of time during which the turnover studies were conducted was such $(18 \mathrm{hr})$ that this span comprised a significant fraction of the transit time of the intestinal cell $(48-60 \mathrm{hr}$ ) from crypt to the tip of the villus. Therefore, it seemed important to be certain that results of turnover experiments were not affected by cell migration. It is possible that a cohort of cells might be labeled with the first injection and then move along the villus to be lost into the lumen. Thus, when the second isotope was administered, there would be very little of the initial isotope remaining. In this cir- 

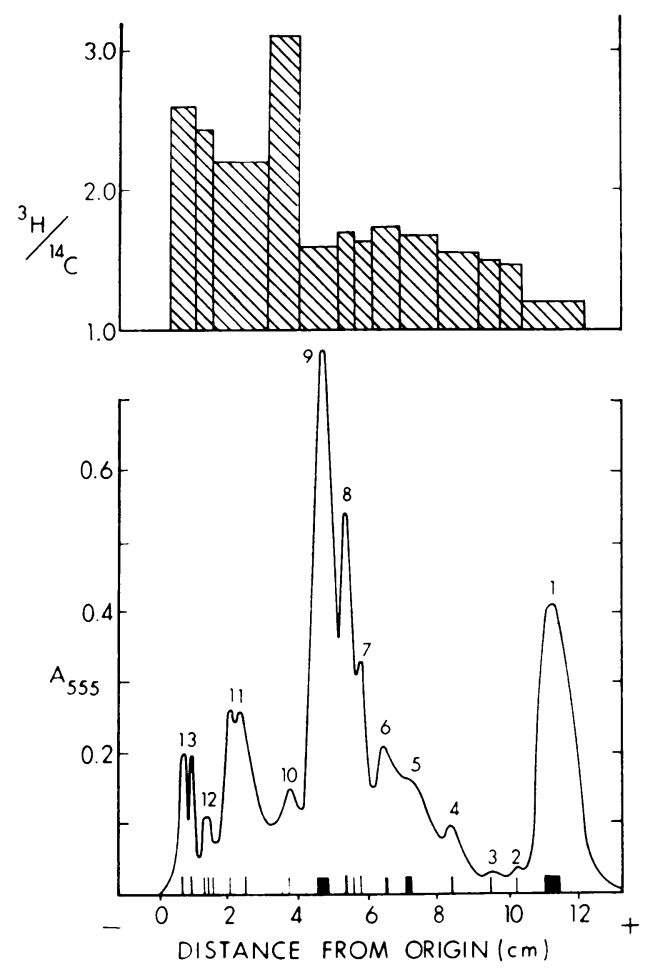

FIGLRE 6 Relative turnover rates of intestinal brush border proteins. Isotopes were administered as in Fig. 7 to two animals. $300 \mu \mathrm{g}$ of brush border protein was electrophoresed in SDS gels as described in Methods. After staining, the gel was sliced to remove the protein bands and counted as described in Methods. Electrophoresis was from left to right. Optical density of the unsliced gel is depicted in the lower panel, with a schematic representation of the protein bands underneath. The numbers correspond to the protein fractions removed by slicing. In some instances, protein bands were too closely approximated to be individually sliced.

cumstance, the two isotopes would be labeling different cells and ${ }^{3} \mathrm{H} /{ }^{14} \mathrm{C}$ ratios would be more difficult to interpret. To answer this question, $50 \mu \mathrm{Ci}$ of leucine $-{ }^{3} \mathrm{H}$ were placed in the jejunum of animals and the jejunum removed at 6,12 , and $18 \mathrm{hr}$. After removal, the intestine was sliced on a cryostat and leucine incorporation measured as a function of position along the intestinal villus. Fig. 4 depicts the results of such an experiment. It is clear that there was heavier labeling of protein in the villus than in the crypt with an intraluminal label, confirming our earlier observations (24). Most importantly, the pattern of incorporation did not vary significantly from 6 to $18 \mathrm{hr}$, although the number of counts was diminished. Thus, it seems very likely that when the second labeled precursor is added at $10 \mathrm{hr}$, incorporation occurs in villus cells which still contain large amounts of the initial label, and that the counts are subsequently lost from all cells along the villus.
The data in Fig. 4 relate to total intestinal protein, and not to brush border alone, since it is not possible to make brush borders from frozen slices. Therefore, after double labeling, intestine was scraped differentially (25) so that villus tips were collected separate from crypts and the lower part of the villi. When brush border proteins from these fractions were analyzed on SDS acrylamide gels, the pattern of ${ }^{3} \mathrm{H} /{ }^{14} \mathrm{C}$ ratio was the same and similar to that seen in Fig. 5 . Thus, it seems unlikely that some proteins are made preferentially in the lower half of the villus, while others are made in the upper half.

The results of experiments to determine the relative turnover of brush border proteins are depicted in ligigs. 5 and 6. Since leucine ${ }^{11} \mathrm{C}$ was administered first, a high ${ }^{3} \mathrm{H} /{ }^{44} \mathrm{C}$ ratio is consistent with rapid turnover. Fig. 5 shows the result obtained after fractionating the acrylamide gel by extrusion. The mean \pm 2 se for con-

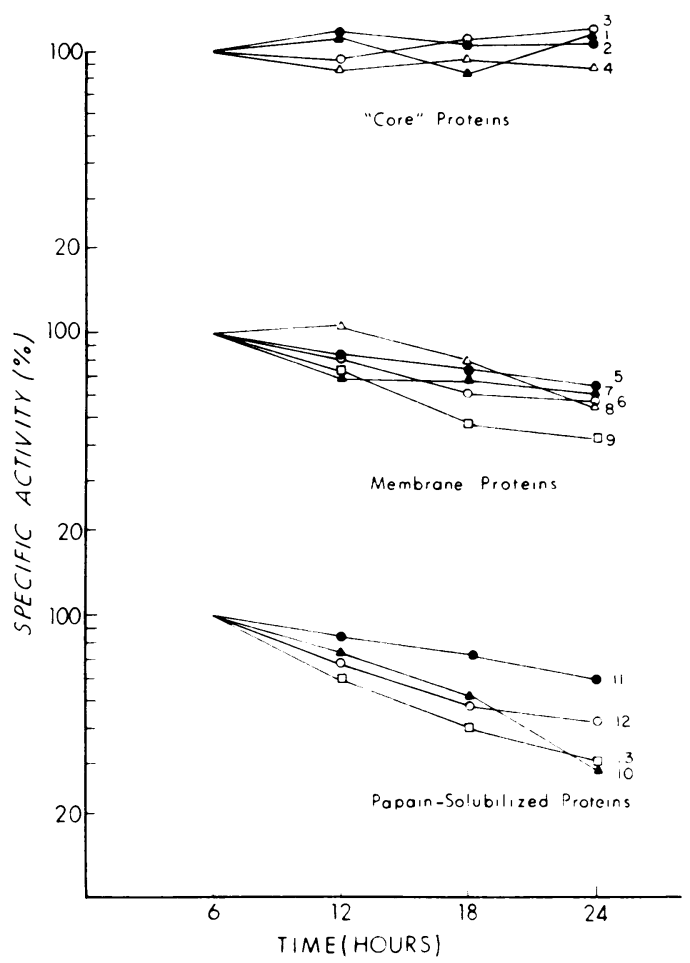

FIGLRE 7 Turnover rates of brush border proteins. 100 $\mu \mathrm{Ci}$ of leucine ${ }^{3} \mathrm{H}$ was placed in the jejunum of eight rats and brush borders isolated $6,12,18$, and $24 \mathrm{hr}$ later from each pair of animals. Animals were allowed water but not food. $300 \mu \mathrm{g}$ of protein was applied to gels, electrophoresed, and scanned as depicted in Fig. 6. The area under each curve was quantitated for each of the 13 fractions and the gels sliced and counted as described in Methods. Slices from three gels were combined for each time point to give sufficient counts. Specific activity at $6 \mathrm{hr}$ was used as $100 \%$ and specific activity of other time points expressed as per cent of the specific activity at $6 \mathrm{hr}$. 
trol brush borders (simultaneous isotope administration) electrophoresed at the same time, are shown. In general, there was some correlation between relative turnover rate and molecular weight. Some of the papain soluble proteins (mol wt 220-250,000), 1-2 cm from the origin, had high turnover rates, other membrane proteins (3-6 $\mathrm{cm}$ from origin) had intermediate turnover rates, and core proteins (7-10 $\mathrm{cm}$ from origin) turned over the slowest. The fact that ${ }^{3} \mathrm{H} /{ }^{14} \mathrm{C}$ ratios (and presumably protein turnover) was heterogeneous in brush borders suggests further that cell migration alone does not account for the rapid turnover of some brush border proteins.

Using a gel extruder, exact correlation between protein bands and gel fractions may be imprecise, so the experiment was repeated using gels which were sliced after staining. In this way, exact correlation between protein bands and counts could be obtained. Fig. 6 shows again that the largest proteins, especially those solubilized by papain (fractions $10-13$ ) had the highest turnover rates. The remainder of the fractions had similar ${ }^{3} \mathrm{H} /{ }^{44} \mathrm{C}$ ratios except for the major "core" protein (fraction 1), which had a low ratio.

Relative turnover rates were measured by still another technique to confirm our findings and to further validate the double isotope method in the intestine. Using leucine $-{ }^{3} \mathrm{H}$ alone, we followed the fall in specific activity with time of individual protein bands in the electrophoretic pattern of brush borders. Protein fractions used were the same as those depicted in Fig. 6, so that not every fraction corresponded to an individual protein band. Specific activity was measured for 24 $\mathrm{hr}$ after incorporation to permit sufficient points to be obtained. Fig. 7 shows that in such an experiment "core" proteins did not turn over detectably. There was turnover of both membrane and papain solubilized proteins and, in general, the turnover time of the latter proteins was faster. There was some overlap in that fraction 9 (alkaline phosphatase) had a fairly rapid turnover by this technique, but not so rapid as fractions 10 and 13 . None of the other membrane fractions (fractions 5-8) had a rapid turnover rate.

In the intestine there is a lag between incorporation of precursor into the cell and its appearance on the brush border (26). Therefore, different rates of isotope turnover might be due to a differential rate of turnover of labeled proteins from the cytoplasm to the brush border, as manifested by a delay in the increase of specific activity of the brush border proteins. To answer this question, rates of incorporation of leucine- ${ }^{-} \mathrm{H}$ into brush border proteins were examined during the first $6 \mathrm{hr}$. Fig. 8 shows that incorporation into all brush border proteins is linear with time. Thus, a difference in the rate of transfer of labeled intracellular protein

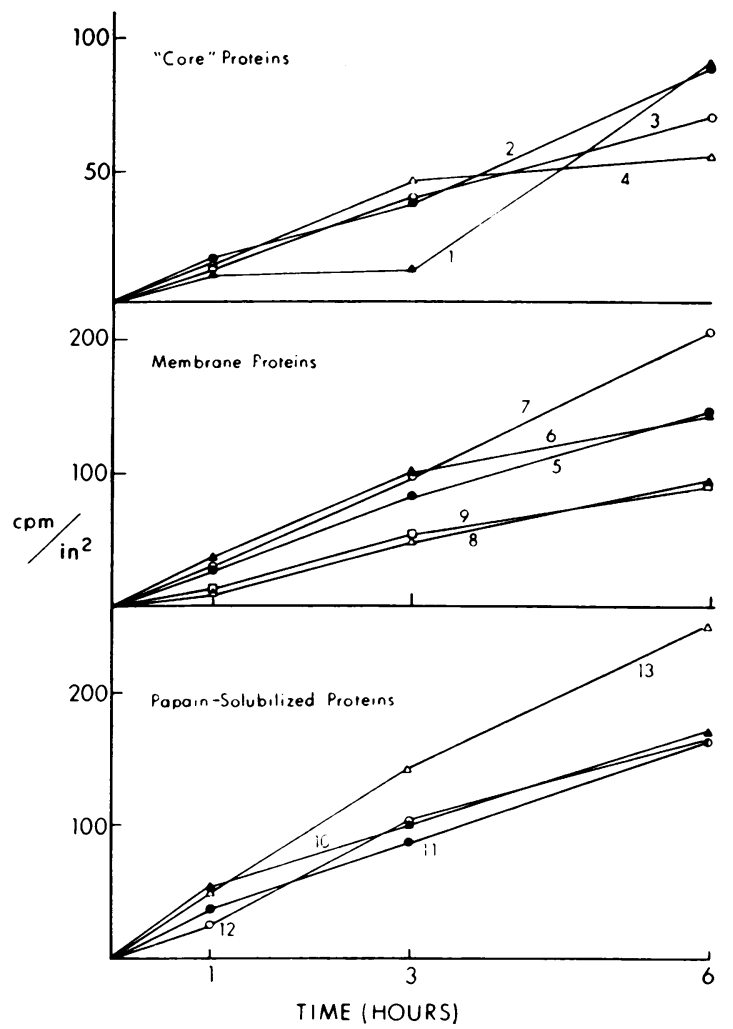

Figure 8 Rate of appearance of labeled protein in the brush border. Isotopes were given and brush borders isolated as in Fig. 7. Proteins were fractionated, counted and quantitated as in Fig. 7. Specific activity is reported as counts per square inch equals $12.5 \mu \mathrm{g}$ of albumin. Counts per minute above background varied from 27 to 228 for the various protein fractions.

into its position on the brush border does not occur and cannot account for the difference observed in relative turnover rates.

\section{DISCUSSION}

The present experiments show that turnover of isotopically labeled protein in the intestinal brush border of the rat is heterogeneous, and that, in general, the largest proteins turn over the fastest. The data in support of this conclusion includes: $(a)$ heterogeneous ${ }^{3} \mathrm{H} /{ }^{44} \mathrm{C}$ ratios using the double isotope technique, and (b) differences in exponential decay of proteins after single isotope injection. However, is it possible that the heterogeneity noted is the result of methodology, since the intestinal mucosa is a heterogeneous tissue with cells continually migrating along the villus?

The use of the double isotope technique has been discussed by Arias et al. (23) as well as the assumptions necessary for its use. The present data suggest that these assumptions are valid for the intestinal system for the following reasons: (a) Labeled proteins 
should be undergoing degradation at the time of sacrifice, otherwise ${ }^{3} \mathrm{H} /{ }^{14} \mathrm{C}$ ratios would reflect only the time required for passage into the membrane. Figs. 7 and 8 show that that is the case, since specific activity increases for $6 \mathrm{hr}$, and the decline in specific activity can be measured starting from $6 \mathrm{hr}$ after administration of the isotope; (b) Labeled precursor should not be metabolized. Over $90 \%$ of the counts recovered in protein are present as leucine, even up to $18 \mathrm{hr}$ after administration of the label: (c) Decay of labeled protein follows first order kinetics. Our earlier data (26) and present studies (Fig. 7) show that this is so in the intestine; $(d)$ Rates of synthesis are the same at the time of addition of both labeled precursors. We have recently shown that there is no diurnal variation on the rate of incorporation of amino acid into brush border (24), so that intraluminal injections at different times of day should not lead to different synthetic rates.

One problem with SDS acrylamide electrophoresis is that the proteins or protein subunits thus separated differ only by molecular weight. Since the disaccharidases have similar sizes it is clear that they would migrate to the same spot during electrophoresis. The same situation is likely true for other bands. Thus, although kinetics of incorporation into each of 13 protein fractions (Fig. 8) appear linear, if the protein content of each fraction were heterogeneous, the incorporation might not be linear for each polypeptide chain. That this situation would obtain for all the fractions seems unlikely. The point to be made is that each group of proteins of a given molecular size is synthesized with the linear kinetics and broken down at heterogeneous rates.

Another problem with SDS gels is that some quenching of counts occurs, and the absolute counts are not high. However, the counts are sufficient (Figs. 3, 5, 8) to permit good counting statistics. Since single proteins are not being isolated, the ${ }^{3} \mathrm{H} /{ }^{14} \mathrm{C}$ ratios from the double isotope technique seems a preferable method by which to measure turnover. The single labeled method of measuring isotopic decay (Fig. 7) generally confirms the results of the double isotope method, but there are some discrepancies. For example, fraction 9 (alkaline phosphatase) seems to have a turnover more rapid than "core" protein fractions $2-4$ in Figs. 5 and 7, but not in Fig. 6. The possible reasons for this include problems with gel fractionation and multiple proteins or subunits in fraction 9. However, the consistent pattern is that the larger proteins turn over most rapidly.

Our data do not really suggest a major methodological problem. However, there may be other possibilities to explain heterogeneous brush border protein. For example, we know that disaccharidases do not appear on the brush border until the cell reaches the junction between crypt and villus (11). It seems possible that "core" proteins are made in the crypts, while membrane proteins are synthesized further out on the villus. Thus, some of the heterogeneity in turnover could be accounted for by normal cell migration and replacement. However, alkaline phosphatase appears on the villus at the same level as the disaccharidases, yet their turnover rates are different (fractions 9 and 11). It seems unlikely that cell replacement can account for all the difference in turnover rates for the following reasons: First, these data are consistent with our previous observations that proteins in whole brush border turn over more rapidly than the entire brush border (26). Second, earlier workers had suggested that protein was made primarily in the intestinal crypt and lower villus, and the cells then migrated to the villus tip with relatively little modification of their protein content. However, we have recently shown that intestinal cells all along the villus are capable of making protein (27). Since protein content of cells does not change along the villus (28), there must be protein turnover in the cells lining the villus. Third, there is no evidence for a cohort of labeled cells moving out to the villus tips (Fig. 4) but rather a gradual decline of specific activity. Admittedly, this experiment does not measure counts in brush borders because of the impossibility in making these organelles from frozen slices. Finally, when brush borders were examined from the tips and base of villi, the patterns of incorporation were the same. This suggests that there is no preferential synthesis of one group of proteins high up on the villus, from where they might be excluded by cell migration during the $18 \mathrm{hr}$ of our experiment.

Das and Gray (29), moreover, have obtained evidence that sucrase, one of the hydrolases on the surface of the brush border, has a half-life of $4.5 \mathrm{hr}$, much faster than cell turnover time. Imondi, Lipkin, and Balis (30) have studied the rates of decay of intestinal enzyme activity after administration of metabolic inhibitors. These workers have found that heterogeneity in turnover time exists and that some proteins have short half-lives (e.g. adenosine deaminase). On the other hand, Rosensweig, Herman, and Stifel (31) have found that some enzymes increase their activity markedly within a few hours after sucrose feeding. The present data lend support to these studies, suggesting heterogeneity of turnover of intestinal proteins, and extend the observations to the brush border proteins. 
Schimke and coworkers (3) had earlier shown that after continuous isotope administration, membranes showed the most rapid isotope turnover, but that there was no clear correlation in liver between the cell fraction and half life of proteins. Later Dehlinger and Schimke (6) showed a correlation in liver plasma membrane between molecular weight and degradation rate, which our studies have confirmed. However, there are some important differences. First, those proteins comprising the intestinal membrane itself ( $\mathrm{mol}$ wt 70 $270,000)$ are larger than those in liver plasma membrane. Second, some of the proteins turning over the fastest are superficially located on the membrane, in that their function is extracellular (20).

The exact anatomic location of the papain solubilized proteins is not clear at this time. Oda and Seki (7) found that the disaccharidases were localized on structures external to the membrane itself, but this view has been disputed recently (32). The "core" proteins are localized on the inner or cellular side of the brush border (8) and probably serve as structural proteins to maintain the shape of the microvilli. These proteins turn over very slowly. The disaccharidases which have a rapid turnover do function as though they were externally placed on the membrane. Thus, it seems unlikely that intracellular degradative enzymes are responsible for their rapid turnover. Preliminary experiments in our laboratory suggest that pancreatic enzymes are in some way responsible for this turnover. There may, then, be only superficial similarities between our findings and those in the liver.

\section{ACKNOWLEDGMENTS}

The author is grateful to Mrs. Carol Goodwin for her excellent technical assistance.

This work was supported by Grants AM 05280 and AM 14038 from the National Institutes of Health of the U. S. Public Health Service.

\section{REFERENCES}

1. Schimke, R. T., and D. Doyle. 1970. Control of enzyme levels in animal tissues. Ann. Rev. Biochem. 39: 929.

2. Rechcigl, M., Jr., editor. Enzyme synthesis and degradation in mammalian systems. 1971. University Park Press, Baltimore. 477.

3. Schimke, R. T., R. Ganschow, D. Doyle, and I. M. Arias. 1968. Regulation of protein turnover in mammalian tissues. Fed. Proc. $27: 1223$.

4. Omura, T., P. Siekevitz, and G. E. Palade. 1967. Turnover of constitutents of the endoplasmic reticulum membranes of rat hepatocytes. J. Biol. Chem. 242: 2389.

5. Kuriyama, Y., T. Omura, P. Siekevitz, and G. E. Palade. 1969. Effects of phenobarbital on the synthesis and degradation of the protein components of rat liver microsomal membranes. J. Biol. Chem. 244: 2017.

6. Dehlinger, P. J., and R. T. Schimke. 1971. Size distribution of membrane proteins of rat liver and their relative rates of degradation. J. Biol. Chem. 246: 2574.
7. Oda, T., and S. J. Seki. 1965. Molecular structure and biochemical function of the microvilli membrane of intestinal cells with special emphasis on the elementary particles. Electron Micros. 14: 210.

8. Eicholz, A., and R. K. Crane. 1965. Studies on the organization of the brush border in intestinal epithelial cells. I. Tris description of isolated hamster brush borders and density gradient separation of fractions. J. Cell Biol. 26: 687.

9. Forstner, G. G., S. M. Sabesin, and K. J. Isselbacher. 1968. Rat intestinal microvillus membranes. Purification and biochemical characterization. Biochem. J. 106: 381.

10. Forstner, G. G. 1971. Release of intestinal surfacemembrane glycoproteins associated with enzyme activity by brief digestion with papain. Biochcm. J. 121: 781.

11. Nordström, C., A. Dahlqvist, and L. Josefsson. 1968. Quantitative determination of enzymes in different parts of the villi and crypts of rat small intestine. Comparison of alkaline phosphatase, disaccharidases and dipeptidases. J. Histochem. Cytochem. 15 : 713.

12. Lowry, O. H., N. J. Rosebrough, A. L. Farr, and R. J. Randall. 1951. Protein measurement with the Folin phenol reagent. J. Biol. Chem. 193: 265.

13. Dunker, A. K., and R. R. Rueckert. 1969. Observations on molecular weight determinations on polyacrylamide gel. J. Biol. Chem. 244 : 5074.

14. Fairbanks, G., T. L. Steck, and D. F. H. Wallach. 1971. Electrophoretic analysis of the major polypeptides of the human erythrocyte membrane. Biochemistry. 10: 2606.

15. Gorovsky, M. A., K. Carlson, and J. L. Rosenbaum. 1970. Simple method for quantitative densitometry of polyacrylamide gels using Fast Green. Anal. Biochem. 35: 359 .

16. Moog, F., H. R. Vire, and R. D. Grey. 1966. The multiple forms of alkaline phosphatase in the small intestine of the young mouse. Biochim. Biophy's. Acta. 113: 336.

17. Jos, J., J. Frezal, J. Rey, M. Lanig, and R. Wegmann. 1967. The histochemical localization of intestinal disaccharidases by a new procedure. Ann. Histochim. 12: 53.

18. Bray, G. A. 1960. A simple efficient liquid scintillator for counting aqueous solutions in a liquid scintillation counter. Anal. Biochem. 1: 279.

19. Zacharius, R. M., and T. E. Zell. 1969. Glycoprotein staining following electrophoresis on acrylamide gels. Anal. Biochem. 30: 148.

20. Miller, D., and R. K. Crane. 1961. The digestive function of the epithelium of the small intestine. I. An intracellular locus of disaccharide and sugar phosphate ester hydrolysis. Biochim. Biophys. Acta. 52: 281.

21. Kelly, J. J., and D. H. Alpers. 1971. Purification and characterization of human intestinal maltase-amylase. Gastroenterology. 60: 780. (Abstr.)

22. Kolínská, J., and G. Semenza. 1967. Studies on intestinal sucrase and on intestinal sugar transport. V. Isolation and properties of sucrase-isomaltase from rabbit small intestine. Biochim. Biophy's. Acta. 146: 181.

23. Arias, I. M., D. Doyle, and R. T. Schimke. 1969. Studies on the synthesis and degradation of proteins of the endoplasmic reticulum of rat liver. J. Biol. Chem. 244: 3303.

24. Alpers, D. H. 1972. Protein synthesis in intestinal mu- 
cosa: the effect of route of administration of precursor amino acids. J. Clin. Invest. 51: 167.

25. Dietschy, J. M., and M. D. Siperstein. 1965. Cholesterol synthesis by the gastrointestinal tract: localization and mechanisms of control. J. Clin. Invest. 44: 1311.

26. James, W. P. T., D. H. Alpers, J. E. Gerber, and K. J. Isselbacher. 1971. The turnover of disaccharidases and brush border proteins in rat intestine. Biochim. Biophys. Acta. 230: 194.

27. Lipkin, M., and H. Quastler. 1962. Studies of protein metabolism in intestinal epithelial cells. J. Clin. Invest. $41: 646$.

28. Koldovský, O., J. J. Herbst, J. Burke, and P. Sunshine. 1970. RNA and DNA in intestinal mucosa during de- velopment of normal and cortisone-treated rats. Growth. $34: 359$.

29. Das, B. C., and G. M. Gray. 1970. Intestinal sucrase: in vivo synthesis and degradation. Clin. Res. 18: 378.

30. Imondi, A. R.; M. Lipkin, and M. E. Balis. 1970. Enzyme and template stability as regulatory mechanisms in differentiating intestinal epithelial cells. J. Biol. Chem. $245: 2194$.

31. Rosensweig, N. S., R. H. Herman, and F. B. Stifel. 1971. Dietary regulation of small intestinal enzyme activity in man. Am. J. Clin. Nutr. 24: 65.

32. Benson, R. L., B. Sacktor, and J. W. Greenawalt. 1971. Studies on the ultrastructural localization of intestinal disaccharidases. J. Cell Biol. 48: 711. 